\title{
Postharvest survival of navel orangeworm assessed in pistachios
}

\author{
by Joel P. Siegel, L.P.S. (Bas) Kuenen, \\ Bradley S. Higbee, Patricia Noble, \\ Richard Gill, Glen Y. Yokota, \\ Rodrigo Krugner and Kent M. Daane
}

Controlling navel orangeworm, a key pistachio pest, is problematic because the moth overwinters in "mummy" nuts. After harvest, there may be more than 30,000 pistachio nuts (mummies) left behind per acre. To provide better information for winter sanitation decisions, we investigated the number of available mummies and their levels of navel orangeworm infestation from winter through early summer in California pistachio orchards. Navel orangeworm mortality was highest from late December through mid-February, and was also higher on the ground than in trees. Mortality on the ground was highest when mummies were tilled or mowed with the groundcover than when nuts were left on the raised berm. Our data indicates that, in contrast to almonds, it is more productive to focus on clearing pistachios from the ground than on removing them from trees. However, winter sanitation procedures also should be augmented in order to destroy more overwintering navel orangeworm.

$\mathrm{M}$ ore than $95 \%$ of U.S. pistachio production occurs in California, primarily in the central and southern San Joaquin Valley (CPC 2007). California pistachio acreage has almost doubled over the past decade to more than 152,000 acres, and pistachios were the second-most valuable California nut crop in 2004 at $\$ 438$ million, trailing only almonds (Boriss 2005).

Pistachios are harvested mechanically, first by shaking nuts from the

\section{tree and then collecting them in a} catch apron. But unfortunately for the grower, the entire crop does not make it to market. Some of the nuts remain in the trees after shaking, and some harvested crop is lost due to spillage (Siegel et al. 2004). Our research focused on the nuts that remain on the ground and in the trees after harvest, known as "mummies." They are costly not only because of their lost market potential but also because they are a resource for a key insect pest of pistachios: the navel orangeworm (Amyelois transitella [Walker]), a moth first described from specimens collected in Mexico (Wade 1961).

Despite its name, the navel orangeworm (NOW) is not a pest of navel oranges but rather a primary pest of California pistachios and almonds, as well as a serious pest of walnuts. Eggs are laid on the exterior of the nut or where the nuts attach to the stem. In some cases, if the hull has split and the kernel is exposed, eggs may be laid directly on the kernel. When the eggs hatch, the larvae crawl on the outside of the nut searching for a breach in the hull in order to gain entry and then burrow into the kernel. Navel orangeworm larvae cause direct damage by feeding on pistachio kernels, and indirect damage by increasing processing costs, reducing nut quality and facilitating aflatoxin contamination of nuts (Doster and Michailides 1994).

In both pistachios and almonds, there are multiple generations of navel orangeworm, and the population increases throughout the summer and early fall; consequently there are more moths in September than in July. The larvae and pupae that do not emerge from nuts spend the winter inside unharvested nuts, called "overwintering" (Caltagirone et al. 1968). Navel orangeworm develop intermittently in these mummies when the temperature exceeds $55^{\circ} \mathrm{F}$ (Engle and Barnes 1983), and oviposition can begin as early as mid-January on mummy almonds in Kern County. Although eggs laid this early are unlikely to develop successfully, those laid at the beginning of February can (Joel Siegel, unpublished data), and in most years emergence of adult moths to start the next generation is well under way throughout the San Joaquin Valley by mid-March. The later navel orangeworm generations, which emerge from August through September, are the most damaging to pistachios because pistachios become 

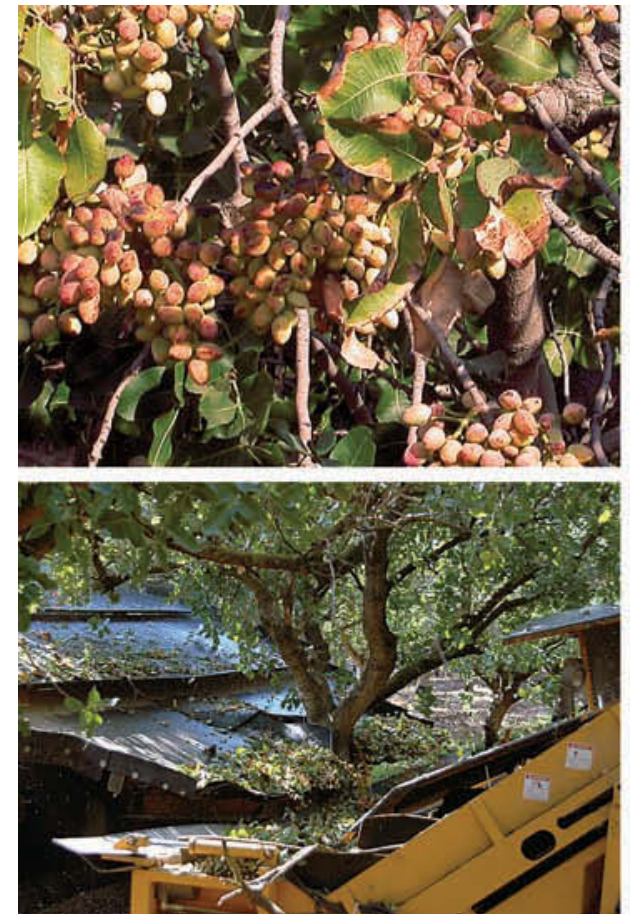

At harvest time, top, pistachios are removed from the tree by mechanical shakers. Bottom, a tree collar captures the nuts.

infested after the hull breaks down, exposing the shell and/or kernel (Beede et al. 1984; Bentley et al. 2005).

Because insecticides do not control the overwintering navel orangeworm population, it is suppressed by sanitation, a laborious process consisting of blowing fallen mummies from the berm (the area immediately surrounding the trunk, containing the irrigation lines) into the drive rows (the area between the tree rows), and then tilling these nuts into the soil. Growers may also shake mummies from the trees and then rake or blow the nuts into the drive rows to be tilled (UC IPM Online 2007).

While orchard sanitation successfully controls navel orangeworm in almonds (Zalom et al. 1984), its effectiveness in pistachios is variable. This is partly because pistachios cannot be readily shredded by tillage and may stick to the berm, and as a result cannot be blown into the drive rows for disking. As many as half of the nuts remain on the berm after blowing because moisture "glues" them to the soil (Siegel et al. 2004). Even when pistachios are successfully tilled into the soil, navel orangeworm larvae can emerge from nuts buried as deep as 6 inches (Bradley Higbee, unpublished data).

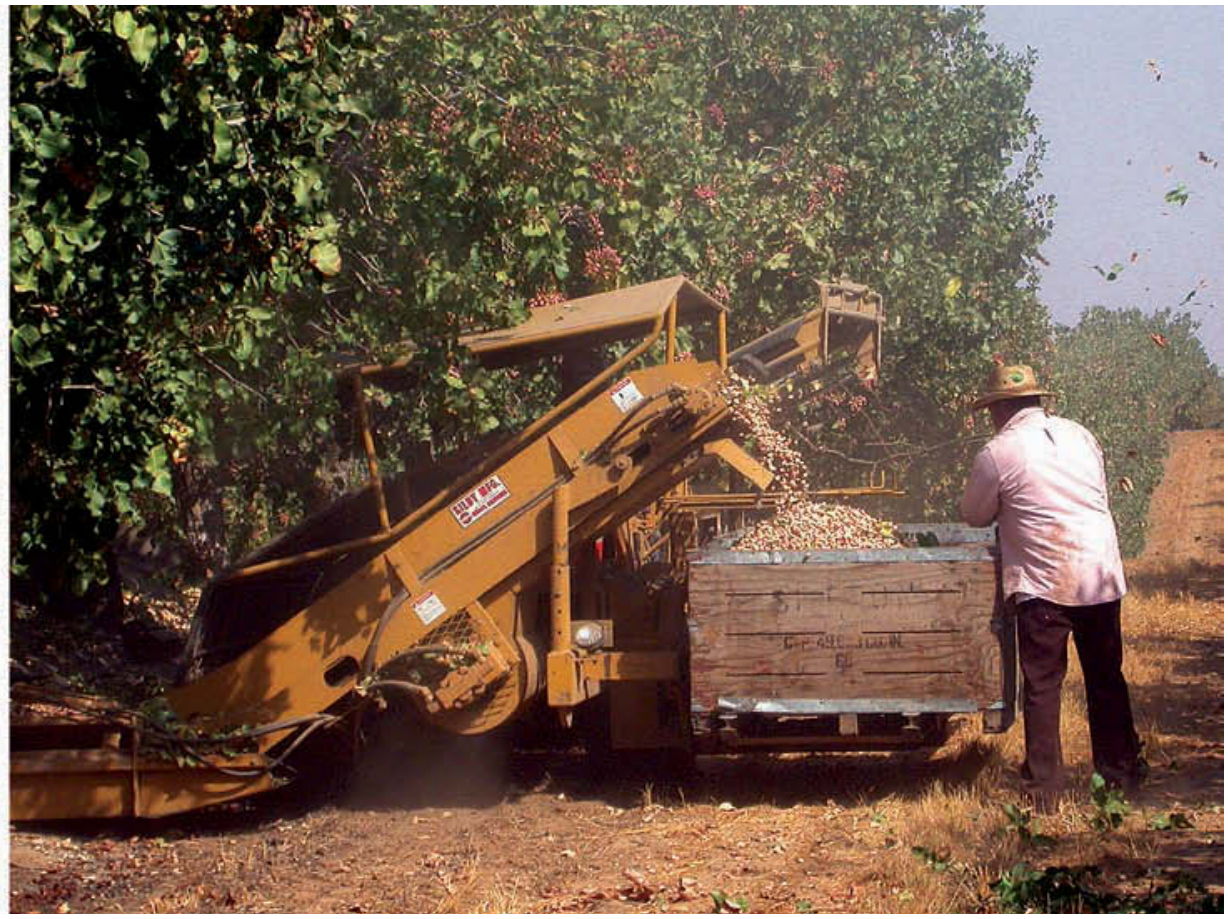

During the pistachio harvest, nuts that are not collected either fall on the ground or are left in the trees. These leftover "mummy" nuts can harbor navel orangeworm over the winter.

Even though unharvested pistachios provide the only available food and shelter for overwintering navel orangeworm populations, the fate of these mummy nuts and the overwintering navel orangeworm has not been extensively studied. We studied pistachio mummy and navel orangeworm prevalence from winter through early summer, using both normal sanitation and experimental ground-management practices.

\section{Prevalence of mummies and worms}

We conducted a series of three studies at S\&J Ranch in Madera County from 2004 to 2007. During winter 2004-2005, a 40-acre pistachio block was selected after harvest and four rows were chosen at random. Within each row, samples of nuts were collected from the berm every three to four trees in December, February, April and June. In addition, two other rows were selected at random ( 0.25 miles per row $)$ and all mummies were collected from the trees in December and February. A total of 175,350 nuts were collected in 2004-2005 from the ground and canopy. In the next study, conducted between April and June 2006, we assessed the prevalence of split nuts and collected 227,286 mummies from the berms in an 80-acre block, as described. In the final study, conducted between January and March 2007, navel orangeworm population density was assessed in a 160-acre pistachio block, and 359,087 mummies were collected from the berm, as described. Findings from all three studies are aggregated in the results presented here.

To calculate the prevalence of navel orangeworm, the mummies collected during all three studies were placed in

\section{Definitions: Processed pistachio nuts}

Upon arrival at the processor, pistachios fall into two broad categories. The first is nuts containing kernels, "filled nuts," which in turn can be subdivided into split and unsplit nuts. About $75 \%$ of harvested nuts are filled nuts with split shells, based on data provided by Paramount Farming Company for 1998 to 2004 (> 1.7 billion pounds field weight). The second category is unfilled nuts or "blanks," which lack kernels. These nuts are removed during processing. 

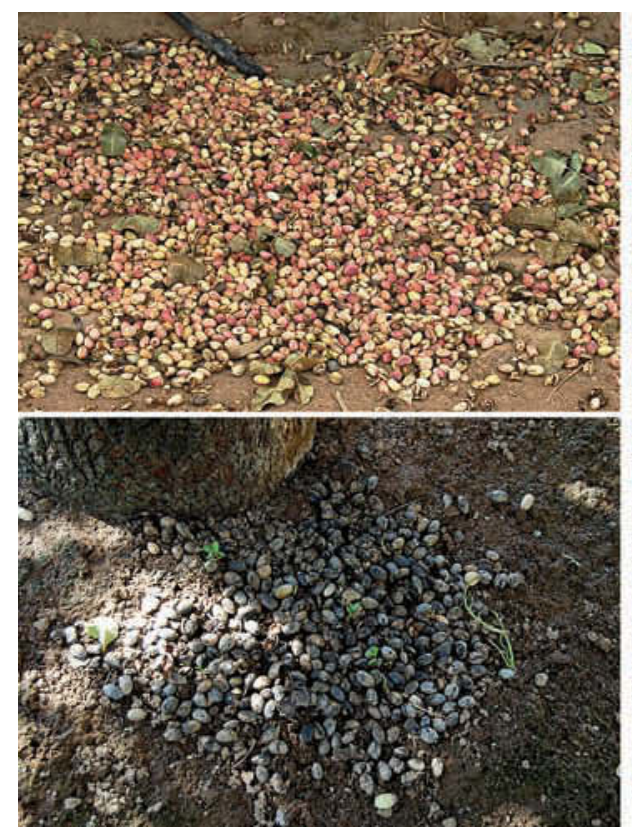

Tens of thousands of pistachios are spilled per acre after a typical September harvest.

5-gallon buckets covered with netting, each containing about 550 mummies. The buckets were held at $80^{\circ} \mathrm{F}$ and checked periodically for adult emergence, which could be seen through the netting. All adults were removed, their numbers recorded, and the days elapsed from collection determined. For each sample date, about $10 \%$ to $30 \%$ of the nuts were removed from the buckets and sorted by hand to determine the percentage of split nuts and blanks. The total number of nuts collected was multiplied by the percentage of split nuts in order to determine the true number of nuts available to navel orangeworm. This is more accurate than calculating infestation by simply dividing the adults by the total number of nuts collected, because closed-shell and blank pistachios cannot be infested.

\section{Ground management practices}

For our ground management study, pistachio mummies were collected on Feb. 19, 2002, from an orchard in Madera County. Four lots of 100 mummies each were dissected to determine navel orangeworm prevalence, which averaged $35.5 \pm 2.5 \%$ per lot, and the remaining mummies $(4,800)$ were used in an experiment conducted in a pistachio research block at the University

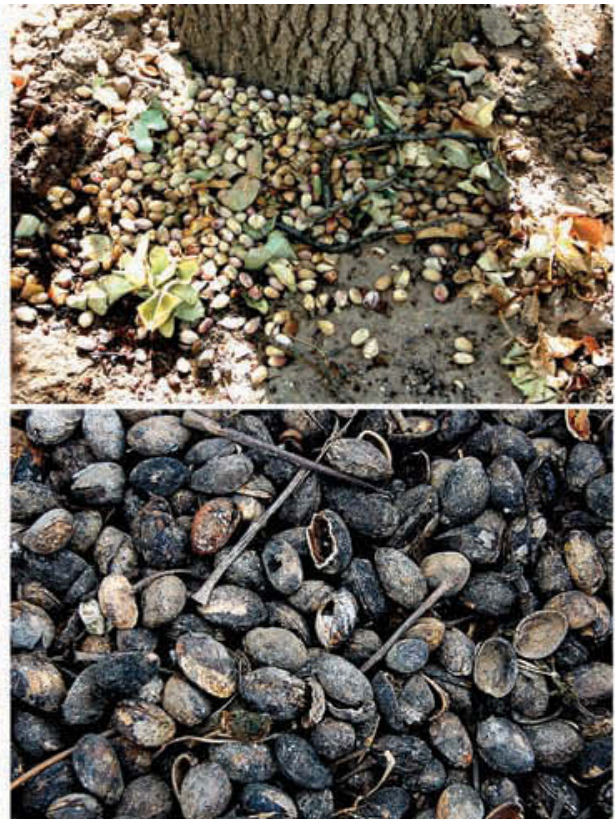

Top, spilled nuts may end up around tree trunks. Bottom, by the following June, the nuts have deteriorated substantially.

of California Kearney Agricultural Research and Education Center in Fresno County.

Ground management in this block consisted of a pre-emergent herbicide application on the berm to keep this section weed-free, but vegetation remained in the drive row. Four treatments were investigated: (1) placing mummies on the berm;

(2) placing mummies in the middle of the drive rows and not mowing them; (3) placing mummies in the middle of the drive rows and then mowing them; and (4) placing mummies in the middle of the drive rows and then tilling them.

Treatments were set in a randomized block design with six replications. Each treatment plot was a 10.76-square-foot section of the berm or drive row that was isolated by cages (wooden frames 10.76 square feet at the base and 3.9 inches high) that were covered on top by organdy cloth immediately after treatment and left open underneath. Two hundred mummies (an estimated 71 navel orangeworm per plot based on the prior dissection) were placed in each plot, and the cages were checked weekly for adult emergence.

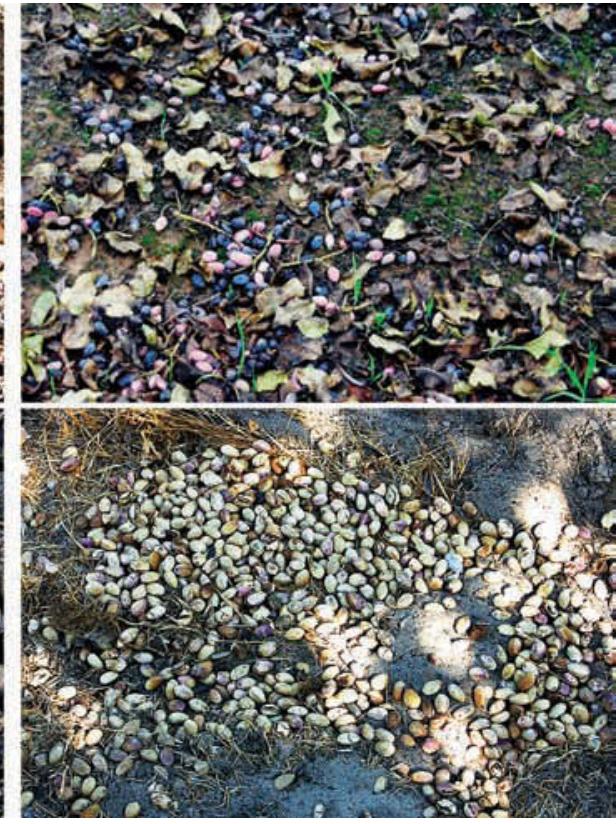

The authors evaluated methods for managing spilled nuts, top, on the berm, and, bottom, in the rows.

\section{Split mummies decrease}

Immediately after harvest, nuts remain on the ground due to spillage. In 2003 - in a separate study not described here - we dissected 9,300 spilled nuts immediately after harvest and determined that the prevalence of splits was 65.1\% (Siegel et al. 2004). 
TABLE 1. Percentage split, unsplit and blank mummies, Madera County, 2005 and 2006

\begin{tabular}{lrrrr}
\hline Sample period & Split & Unsplit & Blank & Nuts sampled \\
\hline Harvest spillage, October & 71.0 & 22.2 & 6.8 & 8,624 \\
Mummy nuts, winter and spring & 30.6 & 3.2 & 66.2 & 14,872 \\
\hline
\end{tabular}

TABLE 2. Infestation based on adult emergence of navel orangeworm (NOW) from mummies collected in Madera County, December 2004-June 2005

\begin{tabular}{|c|c|c|c|c|}
\hline \multirow[b]{2}{*}{ Collection period } & \multirow[b]{2}{*}{ Total nuts } & \multirow[b]{2}{*}{ Split nuts } & \multicolumn{2}{|c|}{ NOW infestation } \\
\hline & & & Total nuts & Split nuts \\
\hline & no. & no. (\%) & & \\
\hline \multicolumn{5}{|l|}{ Berm mummies* } \\
\hline December & 30,000 & $11,460(38.2 a)$ & 7.60 & $20.0 a$ \\
\hline February & 29,500 & $9,300(31.5 b)$ & 1.50 & $4.6 b$ \\
\hline April & 15,000 & $3,056(20.4 c)$ & 0.10 & $0.5 c$ \\
\hline June & 85,500 & $11,050(13.0 d)$ & 0.04 & $0.3 c$ \\
\hline \multicolumn{5}{|l|}{ Tree mummiest } \\
\hline December & 9,250 & $3,352(36.2 a)$ & 3.70 & $10.1 b$ \\
\hline February & 6,100 & $1,000(16.4 b)$ & 1.60 & $9.5 b$ \\
\hline \multicolumn{5}{|c|}{$\begin{array}{l}\text { † Data analyzed using } 2 \times 2 \text { contingency chi square; means followed by the same letter } \\
\text { are not different at } P \leq 0.05 \text {. }\end{array}$} \\
\hline
\end{tabular}

not described here - conducted in Kern County in 2003, when 20 trees were selected at random after the first shake and the remaining 280,500 nuts were removed, sorted and dissected by hand to determine the percentage of split nuts (38.1\%). This is roughly comparable to the $30.6 \%$ split nuts recovered from the berm in our three studies between midwinter/early spring.

The prevalence of split nuts continued to decline, and by mid-June 2005, only $13 \%$ of the mummies in our studies were split (table 2). In contrast, split nuts accounted for almost $43 \%$ of the mummies collected in the same orchard in June 2006, following a dry January and February (data not shown). The seasonal decline in split-nut recovery from the berm is due to a host of factors including germination, rotting, animal feeding and the continuous fall of blank nuts to the ground. Undoubtedly, differences in rainfall timing affect the rate of nut decomposition as well.

We could not assess seasonal changes in split nuts in the trees after February because by April there were few mummies remaining on the trees during the years studied. We obtained a rough estimate of the number of split mummies per acre by combining our data with previously published data on the average number of pistachios per tree. Pistachios are alternate bear- ing, which means that there is an "on" year of high nut production followed by an "off" year where production may drop as much as $60 \%$. Goldhamer and Beede (2004) reported that mature trees in an "on" year produced an average of 12,000 nuts (74\% filled, $26 \%$ blank) in Kings County during the 1991-1992 growing season. Today, a mature tree produces approximately 15,000 nuts in an "on" year, due to improved management practices. Based on the industry average of 135 trees per acre, during an "on" year an acre contains almost 2 million pistachios before harvest, of which approximately 1.44 million are filled (split and unsplit nuts). Assuming $90 \%$ harvest efficiency, the number of filled nuts left behind per acre after one shake is 144,000 per acre, most of which are split. If we assume that the maximum seasonal reduction in split nuts occurred in June 2005, an average orchard would contain 18,720 split nuts per acre (139 per tree) after harvest. If the prevalence observed in June 2006 was the minimum reduction, an average orchard would contain 54,000 split nuts per acre (401 per tree) after harvest was concluded.

\section{Worm survival in mummies}

Navel orangeworm infestation in split nuts collected from the berm declined by $77 \%$ between December 2004
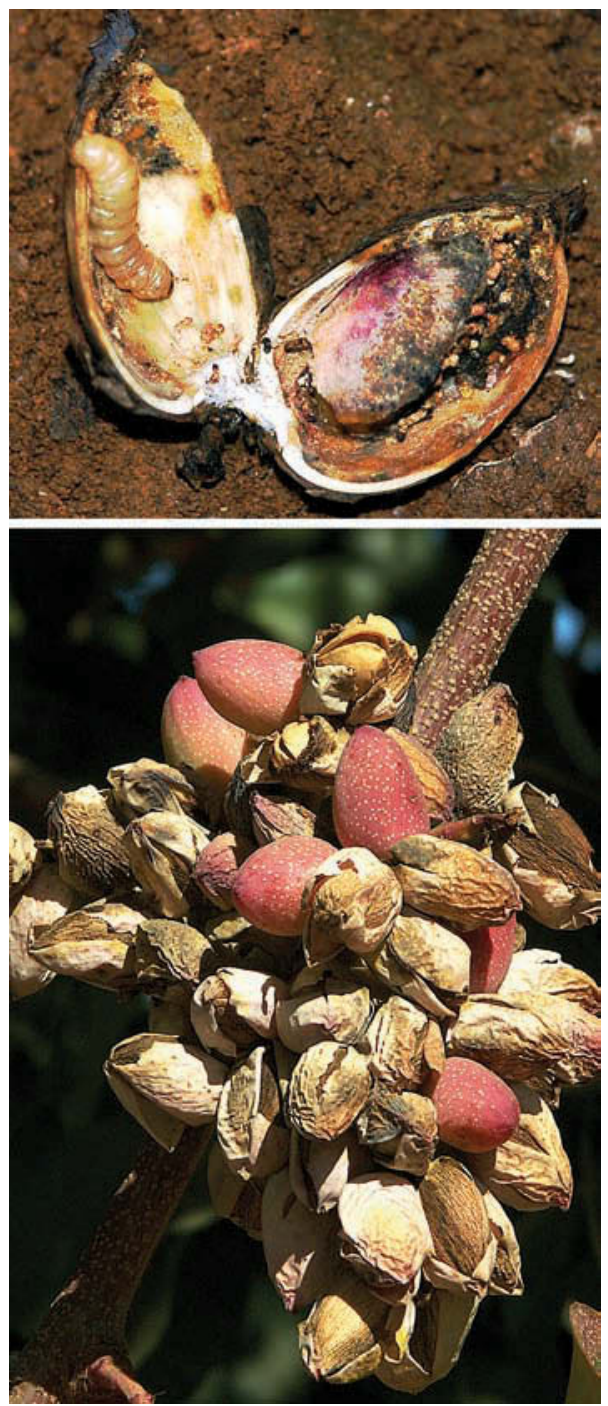

Top, navel orangeworm larvae feed on the kernels and increase aflatoxin contamination. Above, mummy nuts on the tree.

and February 2005, while there was no decline in navel orangeworm infestation of tree mummies during this same period (table 2). Because adult emergence is minimal during this period, we attribute the decline in navel orangeworm density on the ground to mortality. After February, however, adult emergence is a factor. Distinguishing between mortality and emigration in the field is a common problem in all insect mortality studies because the cause of the disappearance in the population is unknown, except for instances when adult emergence is minimal or cadavers are recovered (Siegel et al. 1987).

In our 2005-2006 study, which focused on ground mummies, the decline in navel orangeworm preva- 
TABLE 3. Estimate of density of split nuts and navel orangeworm (NOW) infestation per acre, December 2004-June 2005, Madera County*

\begin{tabular}{|c|c|c|c|c|c|c|}
\hline \multirow[b]{2}{*}{ Month } & \multicolumn{3}{|c|}{ Split nuts } & \multicolumn{3}{|c|}{ Navel orangeworm } \\
\hline & Number & $\begin{array}{c}\text { Stage } \\
\text { decline }\end{array}$ & $\begin{array}{c}\text { Cumulative } \\
\text { decline }\end{array}$ & Number & $\begin{array}{c}\text { Stage } \\
\text { decline }\end{array}$ & $\begin{array}{c}\text { Cumulative } \\
\text { decline }\end{array}$ \\
\hline December & 38,586 & - & - & 7,717 & - & - \\
\hline February & 31,818 & 17.5 & 17.5 & 1,464 & 81.0 & 81.0 \\
\hline Aprilt & 20,606 & 35.4 & 46.7 & 103 & 92.9 & 98.7 \\
\hline Juneł & 13,131 & 36.3 & 66.0 & 39 & 62.0 & 99.5 \\
\hline
\end{tabular}

lence between Jan. 9 and Feb. 6, 2006, was $60 \%$, roughly comparable to our previous finding. Daane et al. (2001) conducted a study in Madera County in which 39,933 mummies were collected between late January and midApril, and also in early June. Navel orangeworm infestation declined 22\% between January and February, and $74.6 \%$ between February and March. We noted declines of the same magnitude in our study during that same period in 2006 and 2007. However, mortality is confounded with emigration: We know that the numbers of navel orangeworm decreased in the samples based on our recovery of adults, but we do not know if this decrease was due to adults emerging before nuts were collected in February and April or whether navel orangeworm died inside the nuts and therefore did not emerge.

Combining our data on navel orangeworm prevalence for 2004-2005 with information on seasonal changes in the density of available mummies, we estimated changes in navel orangeworm density within an acre of pistachios (table 3). This analysis assumed that all filled nuts are split nuts, and ignored infested tree mummies and emigration of adults. Assuming a 95 tree-per-acre planting containing 91 female trees, we begin with an estimated 101,010 split nuts after harvest. This analysis also included the sex ratio of navel orangeworm as a factor, in order to determine if the population would increase in the next generation.

We cannot assume a 50:50 sex ratio in adults emerging from pistachio mummies because the actual male-to-female ratio was 57:43 in both field-collected samples and laboratory studies $(3,844$ adults examined, chi-square analysis, $P<0.0001)$. Consequently, although we estimated the April population to be 103 adults per acre, only 44 of these adults are female. If we assume that a female lays an average of 85 eggs in her lifetime (Wade 1961), there are 3,765 navel orangeworm eggs per acre to begin the first generation of the new crop year. This first generation of the new crop year is laid between February and early June, with peak oviposition occurring from late April into mid-May. The population will increase if more than $2.7 \%$ of these eggs develop into adults, or if mortality is less than $97.3 \%$. The navel orangeworm population will increase further if survival in the succeeding generations - which are laid on new crop nuts - exceeds $2.0 \%$, because the sex ratio of adults emerging from new crop pistachios is 50:50.

Navel orangeworm larvae are more likely to survive in mummies than pupae. In a 2005 Kern County experiment — not described here - researchers at the Paramount Farming Company dissected 176,625 pistachio mummies collected in February and 66,802 mummies collected in March (Bradley Higbee, unpublished data). In February, 10,692 larvae were collected and $84.3 \%$ of these larvae were still alive, but only $14.7 \%$ of the 835 pupae collected were alive. In March, larval survival decreased slightly to $81.8 \%$ (2,445 total) while pupal survival significantly increased to $67.6 \%$ (587 total) $(2 \times 2$ contingency chi square, $P<0.0001$, in both cases). The higher larval than pupal survival indicates that pupae are more susceptible to unidentified mortality factors between February and March.

\section{Ground management reduces NOW}

In our ground management study active management such as mowing groundcover and disking nuts into the

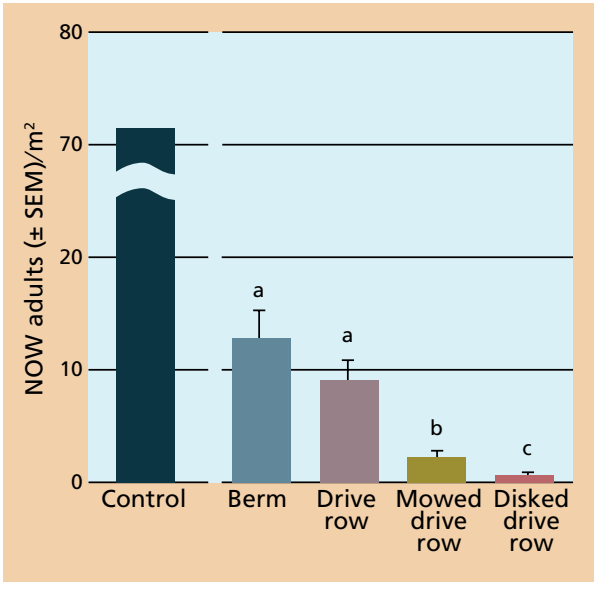

Fig. 1. Numbers of adult navel orangeworm emerging with four pistachio groundcover treatments. Treatment impact was determined using analysis of variance $(P<0.0001$, $\mathrm{df}=3,20, \mathrm{~F}=21.761)$. Treatment separation, indicated by different letters above each bar, was determined using Fisher's least square difference test $(P<0.05)$.

soil drastically reduced navel orangeworm emergence (fig. 1), although the extent of mortality arising from these practices may also be dependent on rainfall and temperature, which we did not measure. Additionally, disks that work the soil to greater depths will bury mummies further underground, increasing navel orangeworm mortality (Bradley Higbee, unpublished data).

To our surprise, however, there was no difference in emergence between mummies placed on the berm and in the undisturbed drive row (ground vegetation) where the ground vegetation was left intact. We hypothesize that moisture in the groundcovers increased mummy rotting, which in turn increased navel orangeworm mortality in undisturbed drive rows. This may not have occurred in this study, however, because our observation interval was too short or because the study year was relatively dry.

\section{Controlling NOW in pistachios}

We found that ground mummies are an important source of navel orangeworm, and that mowing and disking both the groundcover and nuts in row middles reduced navel orangeworm adult emergence. Moreover, burying the mummies kept females from laying eggs in them in the spring or early summer. In our experience, it is more economical to concentrate on removing or destroying mummies on the ground 


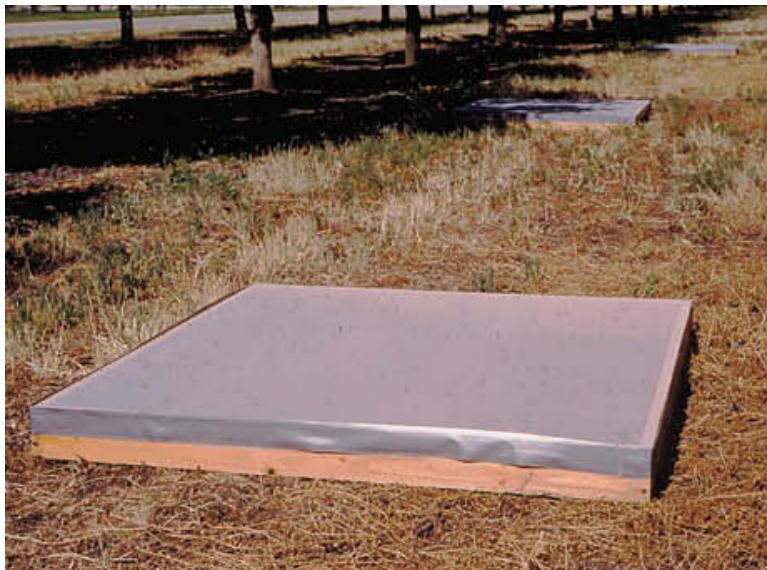

To evaluate ground management practices, several hundred pistachio mummies were placed in each plot prior to treatment, and then covered with a wood frame to monitor the emergence of adult navel orangeworm.

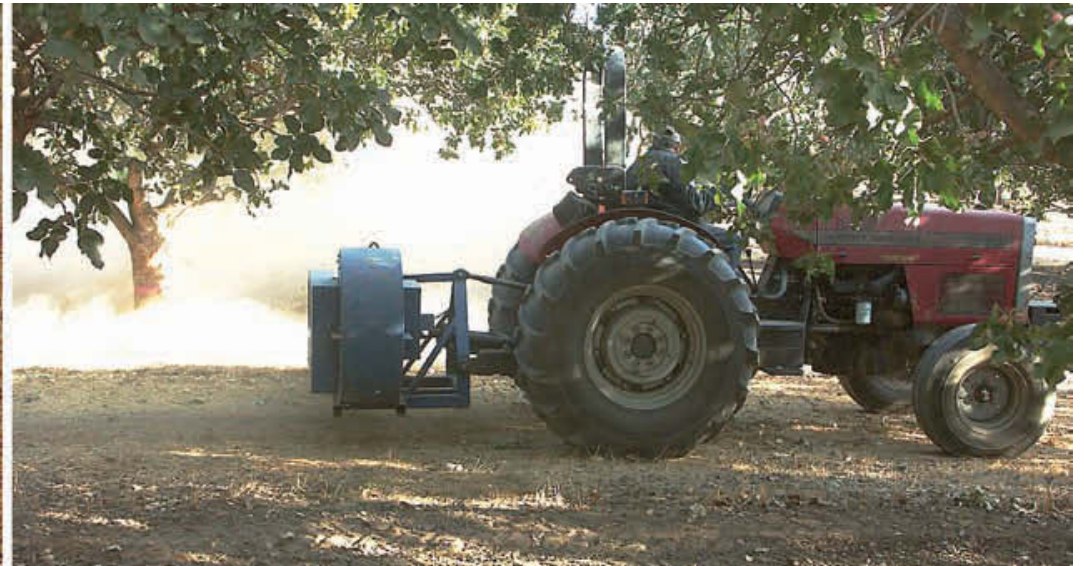

Strategies for managing ground mummies include blowing them off the berm, and mowing and/or disking them into the soil to inhibit navel orangeworm egg-laying. than to shake them from pistachio trees, given the limited resources available to most growers for winter sanitation. However, consistently removing mummies from the berm remains a problem, and in these studies navel orangeworm-infested mummies had higher survival on the berm than those in the row middles.

Our emphasis on removing mummies from the ground for sanitation in pistachios is in sharp contrast to current recommendations for sanitation in almonds, where it is considered critically important to remove mummies from the trees (Zalom et al. 1984; UC IPM Online 2007). Undoubtedly, the importance of pistachio mummies remaining in the trees will continue to be debated, and further research is needed to resolve this issue. Research is also needed to identify the mortality factors responsible for the decline in winter navel orangeworm populations on the ground. It may be possible to augment pistachio sanitation with insecticide use in the fall (Siegel, Higbee, et al. 2006) as well as with entomopathogenic nematodes (Siegel, Lacey, et al. 2006), which have been previously tested in almonds (Agudelo-Silva et al. 1995). Ultimately, navel orangeworm control will be improved by increasing our understanding of the population dynamics of this pest and by integrating preharvest management practices with postharvest sanitation.

J.P. Siegel is Research Entomologist, L.P.S. (Bas) Kuenen is Research Entomologist, and P. Noble and R. Gill are Biological Science Technicians, U.S.
Department of Agriculture Agricultural Research Service (USDA ARS), San Joaquin Valley Agricultural Sciences Center, Commodity Protection and Quarantine Research Unit, Parlier; B.S. Higbee is Research Entomologist, Paramount Farming Company, Bakersfield; G.Y. Yokota is Staff Research Associate, R. Krugner was Laboratory Assistant, and K.M. Daane is UC Cooperative Extension Specialist, Department of Environmental Science,

\section{References}

Agudelo-Silva F Zalom FG, Hom A, Hendricks L. 1995. Dormant season application of Steinernema carpocapsae (Rhabditida: Steinernematidae) and Heterorhabditis sp. (Rhabditida: Heterorhabditidae) on almond for control of overwintering Amyelois transitella and Anarsia lineatella (Lepidoptera: Gelechiidae). Fl Entomol 78:516-23.

Beede RH, Bentley W, Rice RE, et al. 1984. Navel orangeworm management in pistachio. California Pistachio Industry Annual Report, Crop Year 1983-84. www.acpistachios.org/research.php. p 61-8.

Bentley W, Holtz B, Daane K. 2005. Navel orangeworm (Amyelois transitella) (Walker) and obliquebanded leafroller (Choristoneura rosaceana) (Harris) as pests of pistachio. Pistachio Production Manual (4th ed.). http://fruitsandnuts. ucdavis.edu/crops/pistachio index_2005.shtml UC ANR Pub. p 197-203.

Boriss H. 2005. Commodity Profile: Pistachios. UC Agricultural Issues Center, Davis, CA. www.aic ucdavis.edu/profiles/Pistachios-2005.pdf (accessed Dec. 2006)

Caltagirone LE, Meals DW, Shea KP. 1968. Almond sticktights contribute to navel orangeworm infestations. Cal Ag 22(3):2-3.

[CPC] California Pistachio Commission. 2007. California Pistachio Industry Annual Report, Crop Year 2006-2007. www.acpistachios.org/research .php. p 68

Daane KM, Krugner R, Yokota GY, MalakarKuenen R. 2001. Population dynamics of two moth pests, the oblique banded leafroller and the navel orangeworm, and their parasitoids in pistachio orchards. Pistachio Commission Interim Annual Report. www.acpistachios.org/research.php. p 260-75.

Doster MA, Michailides TJ. 1994. Aspergillus molds and aflatoxins in pistachio nuts in California. Phytopathol 84:583-90.

Engle CE, Barnes MM. 1983. Developmental threshold temperature and heat unit accumulation
Policy and Management, UC Berkeley (currently, R. Krugner is Research Entomologist, USDA ARS, San Joaquin Valley Agricultural Sciences Center). The authors gratefully acknowledge the help of James Bettiga of S\&J Ranch and Mike Braga of Nichols Farm for providing field sites, and thank anonymous reviewers for comments on the manuscript. This research was funded in part by the California Pistachio Commission.

required for egg hatch of navel orangeworm (Lepidoptera, Pyralidae). Environ Entomol 12:1215-7.

Goldhamer DA, Beede RH. 2004. Regulated deficit irrigation effects on yield, nut quality and water-use efficiency of mature pistachio trees. J Hort Sci Biotech 79:538-45.

Siegel JP, Higbee BS, Lacey LA, et al. 2004. Use of nematodes for postharvest control of navel orangeworm (Amyelois transitella) in fallen pistachios and assessment of current post harvest cultural control methods. California Pistachio Commission 2004 Production Research Reports. www.acpistachios.org/ research.php. p 179-86.

Siegel JP, Higbee BS, Lacey LA, et al. 2006. Use of nematodes for post harvest control of navel orangeworm (Amyelois transitella) in fallen pistachios and assessment of current post harvest cultural control methods. California Pistachio Commission 2005 Production Research Reports. www.acpistachios.org/ research.php. p 177-84.

Siegel JP, Lacey LA, Higbee BS, et al. 2006. Effect of application rates and abiotic factors on Steinernema carpocapsae for control of overwintering navel orangeworm (Lepidoptera: Pyralidae, Amyelois transitella) in pistachios. Biol Control 36:324-30.

Siegel JP, Maddox JV, Ruesink WG. 1987. Survivorship of the European corn, Ostrinia nubilalis (Hübner) (Lepidoptera: Pyralidae) borer in Central Illinois. Environ Entomol 16:1071-5.

UC IPM Online. 2007. UC Pest Management Guidelines: Pistachio, Navel Orangeworm. www.ipm.ucdavis .edu/PMG/r605300111.html (accessed May 2007).

Wade WH. 1961. Biology of the navel orangeworm, Paramyelois transitella (Walker), on almonds and walnuts in northern California. Hilgardia 31:129-71.

Zalom FG, Barnett WW, Weakley CV. 1984. Efficacy of winter sanitation for managing the navel orangeworm, Paramyelois transitella (Walker) in California almond orchards. Prot Ecol 7:37-41. 